\title{
I. I. Бегаль,
} аспірант, Аержавна установа "Інститут економіки природокористування та сталого розвитку Національної академії наук України", м. Київ ORCID ID: 0000-0003-4452-8969

DOI: $10.32702 / 2306-6792.2020 .11 .141$

\section{АЕФІНІЦІЇ ЕКОНОМІЧНИХ КАТЕГОРІЙ РЕГУАЮВАННЯ ЗЕМЛЕКОРИСТУВАННЯ В УМОВАХ АЕЦЕНТРААІЗАЦІЇ ВАААИ}

\author{
I. Behal, \\ Postgraduate student, Public Institution "Institute of Environmental Economics \\ and Sustainable Development of the National Academy of Sciences of Ukraine", Kyiv
}

\section{DEFINITIONS OF ECONOMIC CATEGORIES OF LAND USE REGULATION IN THE CONDITIONS OF DECENTRALIZATION OF POWER}

У роботі досліджено понятійно-категоріальний апарат системи регулювання землекористування в Україні. Виявлено ряд недоліків, як-от: відсутність ієрархії в значеннях у відповідності до рівнів економічних процесів; дублювання визначень; застарілість формулювань. Сформульовано методичні рекомендації для формулювання та аналізу термінології. Було проведено історико-етимологічний аналіз терміну "землеустрій" та проаналізовано традиції формулювання поняття "землекористування" у вітчизняній економічній і практичній літературі. Сформульовано низку визначень і нових термінів, що описують сутність процесу землекористування на різних рівнях господарськоїдіяльності. Запропоновано зміну підходу до формулювання термінів "землеустрій", "землекористування", "земельні ресурси" в законодавчому забезпечені та практичній діяльності. Запропоновано удосконалену структуру документації із землеустрою Аля регіонального рівня щодо забезпечення регулювання раціонального землекористування.

Institutional support (as a set of formal and informal rules) for the management of any process should be based on a clear categorical conceptual apparatus that describes the essence of a particular object or phenomenon. Incorrect formulation and interpretation of terminology leads to distortions of the essence of phenomena and, accordingly, distortions of the essence of the economic process.

Without defining clear definitions of "setting boundaries", defining terms, an effective system of rule-making and rule-making in Ukraine is impossible.

The conceptual and categorical apparatus of land use in Ukraine was studied. A number of shortcomings were identified, such as: lack of hierarchy in values in accordance with the scale of economic processes; not delimitation of concepts; obsolescence of wording. A historical and etymological analysis of the term "land management"was conducted and the traditions of formulating the concept of "land use" were analyzed. A number of new meanings and terms describing the essence of the land use process at different levels of economic activity are formulated. It is proposed to improve and change the wording and use of the term "land management", "land use", "land resources", as well as to change the structure of documentation for the provision and regulation of rational land use.

A new understanding of the terms land management, land use and land resources at the national, regional and local levels has been formulated.

In our opinion, the understanding of the function of land resources as a subject of labor can be much broader, and formed not only in terms of production (operational), but also architectural (formative), based on the aesthetics of perception and quality of the environment.

Production and architectural relations should be developed on the basis of the concept of sustainable development and aimed at preserving, protecting, improving the organization of multifunctionality of land resources. The ecological relationship should be based on the principles of protection and creation of conditions for the preservation of elements of living and non-living nature.

Ключові слова: землекористування, землеустрій, землевпорядкування, земельні ресурси, регулювання, дечентралізачія.

Key words: land use, land management, system of land use, land resources, decentralization.

\section{ПОСТАНОВКА ПРОБЛЕМИ У ЗАГАЛЬНОМУ ВИГЛЯДІ ТА ІІЇ ЗВ'ЯЗОК ІЗ ВАЖЛИВИМИ НАУКОВИМИ I ПРАКТИЧНИМИ ЗАВДАННЯМИ}

Усесторонній розвиток національної економіки з метою забезпечення суспільного добро- буту не можливий без дієвої системи права й ефективного інституціонального забезпечення. Поширеною є експертна думка, що в Україні нормативно-правове забезпечення економічних відносин несе відбиток старих економічних форм господарювання, які перебувають у не- 
узгодженості із вимогами сьогоденням. Зовнішнє середовище постійно змінюється та обумовлює потребу в трансформації існуючих норм і правил функціонування системи, в тому числі і землекористування як одної з прикладних галузей економіки природокористування. Сьогодні можна знайти безліч версій трактування базових ключових термінів економіки природокористування таких як "земельні ресурси" "землеустрій", "землевпорядкування", "землегосподарювання" та ін. Це призводить до погіршення науково-дослідного процесу та довготривалої невизначеності напряму подальшого розвитку у вузькому значенні - землі, тобто усіх галузей і секторів економіки, що пов'язані з використанням земельних ресурсів, при виникненні земельних відносин, а в широкому - всієї національної економічної системи.

\section{АНАЛІЗ ДОСЛІДЖЕНЬ І ПУБЛІКАЦІЙ}

Проблемою формулювання і наповнення системи наукових дефініцій вітчизняної сфери землекористування у різний час займалися такі науковці: I.К. Бистряков, I.C. Будзилович, А.С. Аобряк, И.М.Аорош, О.С. Аорош, О.М. Гарнага, Т.О. Євсюков, Ш.І. Ібатуллін, В.М. Кривов, Р.М. Курильців, А.Г. Мартин, М.Я. Новаковський, О.С. Новоторов, Ю.М. Палеха, А.М. Третяк, Н.А. Третяк, А.М. Сундук, М.А. Хвесик та ін. Проте слід зазначити, що тема наукового забезпечення понятійно-категоріального апарату регулювання сфери землекористування недостатньо глибоко досліджена й узгоджена, потребує складніших новітніх теоретико-методологічних підходів, що формуються на межі історичних, економічних і правових значень, що в сукупності дасть змогу розв'язати наукове завдання, зокрема, інституційного та інституціонального забезпечення землекористування в умовах децентралізації влади в Україні.

\section{META CTATTI}

Метою дослідження є науковий пошук та уточнення базових термінів і понять системи регулювання землекористування, а також формулювання пропозицій щодо їх удосконалення.

\section{ВИКЛАД ОСНОВНОГО МАТЕРІАЛУ ДОСЛІДЖЕННЯ}

Інституціональне забезпечення як сукупність формальних і не формальних правил управління будь-яким процесом має будуватися на чіткій системі термінів та визначень основних категорій, яка однозначно й без можливих викривлень і різнотлумачень описує суть певного предмету чи явища. Неправильне формулювання і ймовірне множинне трактування термінів може призводити до викривлень сутності явищ та економічного процесу загалом, стати перешкодою в досягненні цілей, що ставиться регулятором/адміністратором системи. Без визначення чітких дефініцій (або встановлення меж системи), неможлива ефективна система нормотворення та нормопроєктування в Україні.

Необхідно врахувати, що дефект дефініцій актів офіційного юридичного тлумачення - це навмисні або випадкові техніко-юридичні неточності, упущення, похибки у їх формулюваннях, які спотворюють зміст, цілі акта офіційного тлумачення, або ускладнюють його реалізацію (прогалини колізії, надмірності, дубльована неадекватність опису тощо) [1].

Переважна більшість економічних, екологічних і соціальних проблем сьогодення у сфері землекористування свідчать про те, що суб'єкти офіційного тлумачення завдяки своїй чисельності й жорсткій підпорядкованості тенденціям розвитку держави в новітніх умовах ще не змогли створити систему сформованого ними понятійного апарату в актах офіційного роз'яснення. У зв'язку із цим мають місце інтерференція, повтори, колізії та суперечності в дефініціях актів офіційного тлумачення, що істотно знижує ефективність реалізації чинного законодавства [2].

На нашу думку, мають місце такі методологічні аспекти формулювання та аналізу понять у сфері регулювання землекористування, однак, відзначимо, їх можна поширити і на всю систему регулювання національної економіки:

1. Економічні терміни, як правило, є багатозначними та різномасштабними по своїй сутності, тому їх визначення має чітко відповідати масштабу економічного процесу, до якого воно відноситься чи які описує.

2. Термін повинен мати чіткі істотні ознаки, а саме: з'ясування властивостей описуваного предмета; відмежування його від інших суміжних предметів чи явищ.

3. Кожне поняття має свій історичний контекст, який відповідає певним зовнішнім і внутрішнім умовам і процесам, що склалися чи відбуваються у відповідний проміжок часу. У разі зміни зовнішніх умов майже завжди змінюються внутрішні, відтак, понятійно-категорі- 
альний апарат теж зазнає змін або взагалі втрачає актуальність.

В Україні землекористування є важливим елементом економіки, адже земельні ресурси є базовим та визначальним природним ресурсом, який задіяний прямо й/ або опосередковано до абсолютно усіх видів економічної діяльності. Але, слід зазначити, що саме наповнення терміну "землекористування" в Україні ще не сформовано остаточно й однозначно.

Так, В.М. Аругак під землекористуванням розуміє систему користування землею, регламентовану законодавством для різних категорій земель, власників землі та землекористувачів. Термін "землекористування" означає земельний масив, територію, що перебуває у власності чи користуванні [3]. Під землекористуванням розуміють також процес використання людиною земельної ділянки для задоволення своїх потреб, 3-поміж них і матеріальних [4]. У таблиці 1 зазначено основні, базові терміни, які формують систему землекористування в Укpaїні.

Серед багатьох аспектів глобальних змін економічних відносин і стану (компонентів) навколишнього середовища, характер землекористування має вирішальний влив на екосистему. Сьогоднішній споживацький підхід, коли земля в різних галузях розглядається лише як засіб виробництва, предмет праці та просторовий базис розміщення виробництва і господарства, вичерпав себе. Економічно, екологічно й соціально ефективне землекористування являється центром найважливіших викликів прийдешніх десятиліть: забезпечення населення достатньою кількістю продуктів харчування, підвищення стандартів проживання мільйонів людей, що перебувають за межею бідності, а також збалансування екосистеми планети в процесі людської діяльності [10].

Відомо, що земля слугує людині не тільки як головний засіб виробництва в сільському господарстві, а й є територіальним базисом для накопичення інших благ - майнових, соціальних, культурних та інших. Тому на цьому етапі земельних перетворень, насамперед, належить звільнитися від вузькості, переважно у вітчизняних мікроекономічних системах, уявлень про землю, як тільки про елемент суспільного виробництва. Земля - об'єкт значно складніший. Це - і грунт та інші природні ресурси, територія розміщення, місце буття людини, надра, а також простір над та під земельною поверхнею. Наведений розподіл функцій землі на шари не тільки ускладнює правові, економічні та інші відносини, але й понижує їі економічне значення [11].

Недоліком формулювань, зазначених у таблиці 1, є відсутність ієрархічного підходу до визначення терміну землекористування у відповідності до рівнів економічних процесів та явищ.

Ми погоджуємося із цитованими у таблиці 1 авторами щодо формулювання процесуальної частини визначення землекористування, але вважаємо, що не зовсім коректно абстрагувати термін у контексті масштабу виключно до регіонального чи місцевого рівня. На наш погляд, "землекористування" повинно мати дві форми: загальну та конкретну - на національ- 
ному, регіональному, місцевому, господарському рівні.

Вважаємо, що загальну форму визначення терміну землекористування доцільно подати у наступній формі.

Загальне землекористування - це безперервний процес використання індивідом, суспільством і живими організмами земельних ресурсів як базової природної матерії та їх інтегральних корисних властивостей (функцій) 3 метою свого життєзабезпечення й реалізації приватних і суспільних намірів та цілей.

Під земельними ресурсами в загальному формулюванні тут ми розуміємо компоненти земної кори (твердого утворення) в поєднанні 3 підземними і поверхневими водами (рідкого утворення) та результатами їньої інтегрованої взаємодії з компонентами навколишнього (природнього й техногенного) середовища на відповідній проекції просторової площини на земну поверхню.

Під національним землекористуванням необхідно розуміти процес використання соціально-етнічною спільністю (народом) земельних ресурсів з метою сталого його розвитку та добробуту у межах певної країни.

На національному рівні земельні ресурси являються базовим економічним ресурсом, основним засобом виробництва в національній економіці (сукупності галузей і сфер виробництва), просторовим базисом системи розселення, а також предметом спільної праці природи та суспільства (народу), якому цей ресурс підпорядковується.

Прийнято вважати, що особливою ознакою землі як засобу виробництва є поєднання функцій предмета і засобу праці в одному процесі виробництва [13].

Aле, на нашу думку, розуміння функції земельних ресурсів як предмета праці може бути значно ширшим і формуватися не тільки у виробничому відношенні (експлуатаційному), але й на архітектурному (покращуючому) підході, що базується на естетиці сприйняття та якості організації навколишнього середовища.

Виробничий та архітектурний функціональний підхід має розвиватися на засадах концепції сталого розвитку і бути направленим на збереження, покращення, охорону та розвиток багатофункціональності земельних ресурсів.

Найбільш необхідним та важливим вважаємо формулювання понять, які описують економічні процеси та явища притаманні місцевому і регіональному рівням регулювання землекористування.
Землекористування на регіональному рівні повинно базуватися на національному рівні, але може і повинно містити ознаки, які притаманні певному регіону чи громаді.

На нашу думку, регіональне землекористування - це процес використання базовим суб'єктом місцевого самоврядування (громадою) земельних ресурсів із метою сталого їх розвитку та забезпечення добробуту мешканців громади та держави загалом.

Земельні ресурси на регіональному рівні являються базовим економічним ресурсом, основним засобом виробництва (знарядАям праці) в сільському, лісовому, водному господарстві та гірничо-добувній промисловості, а також є просторовим базисом розселення та розвитку інших типів економічної діяльності. Водночас, земельні ресурси на цьому рівні $є$ результатом впливу природи та результатом, предметом і засобом праці мешканців громади. Являються основою для організації землекористування місцевого та господарського рівнів.

Місцеве землекористування - використання земельного ресурсу у формі земельної ділянки, що має встановлені межі, правовий, економічний, екологічний та інституціональний статус, встановлений відповідно до державного землеустрою.

Необхідно враховувати, що земельна ділянка - це не тільки частина земної поверхні 3 установленими межами, певним місцем розташування, з визначеними щодо неї правами [14], а також встановленими умовами їі використання.

Аержавні умови, щодо використання земельних ресурсів визначаються відповідно до встановленої системи землеустрою, що є одним 3 найбільш вагомих елементів інституціональної системи землекористування.

Землеустрій - це сукупність соціальноекономічних та екологічних заходів, спрямованих на регулювання земельних відносин та раціональної організації території адміністративно-територіальних одиниць, суб'єктів господарювання, що здійснюються під впливом суспільно-виробничих відносин і розвитку продуктивних сил [14].

Aле наведене формулювання вважаємо не зовсім коректним, оскільки воно сформульоване з трьох пов'язаних між собою характеристик і водночас - окремих складових одного процесу - землекористування:

- управління як сукупність соціально-економічних та екологічних заходів;

- політики як діяльності щодо регулювання земельних відносин; 
— планування як інструменту раціональної організації території адміністративно-територіальних одиниць та суб'єктів господарювання.

У контексті нашого дослідження відзначимо, що існуючі дослідження відзначаються досить широкою інтерпретацією складу та змісту землеустрою і землевпорядних робіт [15]. Певну термінологічну проблематику пов'язуємо 3 неоднозначністю застосування термінів "землеустрій" та "землевпорядкування". Якщо звернутися до Великого тлумачного словника сучасної української мови [16], то в ньому землевпорядкування (землевпорядження, землеустрій) трактується як "сукупність заходів щодо організації землі і користування нею". Тобто ці терміни розуміються як синоніми. Водночас у цьому ж словнику слово "устрій" трактується як "порядок, система організації чого-небудь" [15].

Вивчаючи зародження терміна "землеустрій" та еволюцію його змісту в сучасних умовах, I.C. Будзилович зазначає, що цей термін уперше виник у російській та українській мовах у 1906 році з появою проєкту "Положення про землеустрій" (рос. землеустройство) [21]. У 1906 р. було створено "комитет по землеустроительным делам" (орган для обговорення питань підготовки і проведення в Російській імперії в 1906-1917 роках Столипінської аграрної реформи). Комітет підготував наказ, а пізніше закон "Про селянське землеволодіння та землекористування" 1906 року, "Тимчасові правила про відведення надільної землі до одних місць" 1908 року, "Правила про землевпорядкування цілих сільських товариств" 1909 року, "Положення про землеустрій" 1911 року та низку інших. Важливим $€$ розуміння, що саме визначення "землеустрою" в часи Столипінської реформи не було сформоване, але під ним розумілася певна сукупність дій, направлених на реалізацію розроблених норм (законів) аграрної реформи.

У 1911 році термін "землеустрій" (землеустройство), на нашу думку, мав тільки одне пряме значення - "облаштування" (син. при- стосування, адаптація, впорядкування) земель до нового укладу суспільних та виробничих відносин, або до певного державного устрою (син. лад, уклад, порядок, режим) системи землекористування.

Аналізуючи таблиці 2, можна зробити висновок, що нині термін "землеустрій" може вживатися в абсолютно двох різних контекстах:

1) "землеустрій" як землевпорядна дія (землевпорядкування);

2) "землеустрій" як режим встановлений державою (державний землеустрій).

Сьогодні в законодавстві України не має чіткої межі між вживання терміну "землеустрій" у значені "державного землеустрою" та "землевпорядкування". На нашу думку, відсутність розмежування цих понять вносить певні колізії й неузгодженість у науковому забезпеченні, навчальному процесі та нормотворенні, оскільки постійно виникає потреба правильного зазначення й уточнення контексту його вживання та застосування. Відсутність 


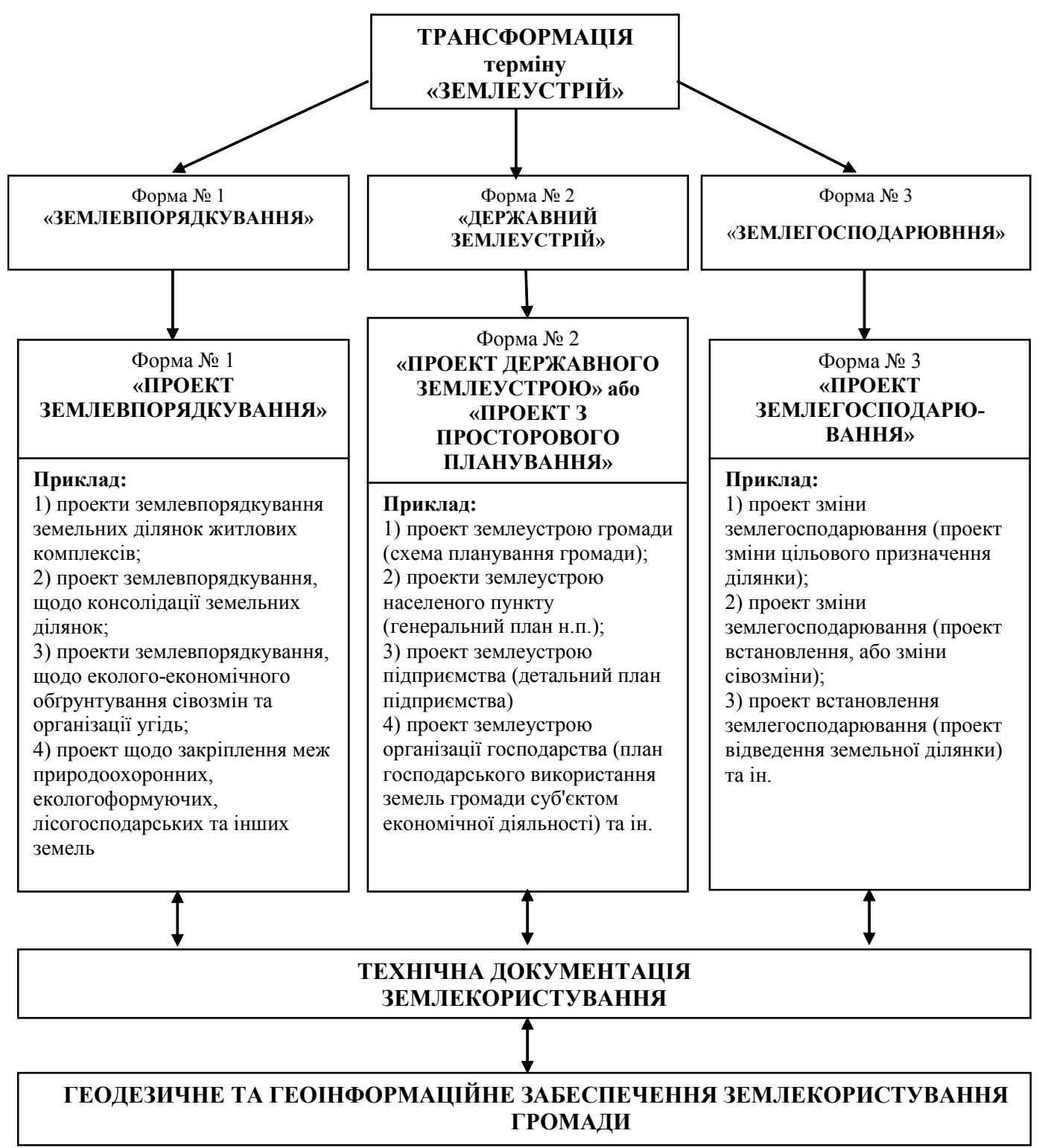

Рис. 1. Авторська пропозиція удосконалення інституціонального забезпечення землекористування в Україні

чітких розмежувань допускає ймовірність дефектів юридичних і наукових тлумачень.

На рисунку 1 наведено авторську пропозицію щодо розподілу значень терміну "землеустрій".

Зокрема вважаємо, що землеустрій має такі три форми:

1) землевпорядкування - це сукупність заходів і дій на державному, регіональному та місцевому рівні спрямованих на раціональну й ефективну організацію господарювання, що відповідає державному землеустрою;

2) державний землеустрій - сукупність встановлених або погоджених умов, норм, обмежень, заходів, планів щодо використання, охорони чи розвитку земельних ресурсів як на конкретних землях, так і загального земельного фонду. Аержавний землеустрій складаєть- ся з системи державних, приватних і комунальних інститутів (суб'єктів) та інституцій (формальних та не формальних норм), що регулюють землекористування на усіх рівнях щодо раціонального використання земельних ресурсів землевласниками, землекористувачами і суспільством загалом;

3) землегосподарювання - це стан, або процес ведення певного виду господарської діяльності на конкретній земельній ділянці, з певною метою та цілями, що відповідає інтересам суспільства і сприяє розвитку економіки.

Також на рисунку 1 наведений приклад реалізації такого підходу в практичній діяльності, а саме - зміна структури організації розроблення документації щодо регулювання землекористування. 
На нашу думку, в нових умовах сьогодення наведений підхід необхідно застосовувати в удосконаленні законодавства та практичній діяльності. Необхідним є більш детальне дослідження розподілу та оптимізації видів проєктної документації різних видів щодо регулювання раціонального землекористування, а та-

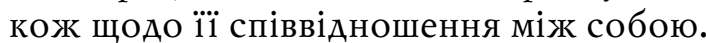

\section{ВИСНОВКИ З ПРОВЕДЕНОГО ДОСЛІДЖЕННЯ I ПЕРСПЕКТИВИ ПОДАЛЬШИХ РОЗВІДОК У ЦЬОМУ НАПРЯMI}

Різноманітне трактування ключових термінів економіки природокористування, як-от: "землеустрій", "землевпорядкування", "землекористування", "земельні ресурси" призводить до погіршення якості наукового забезпечення проблеми стимулювання сталого використання й охорони земельних ресурсів, а також похідних від неї. Без визначення чітких дефініцій неможлива ефективна система нормотворення та нормопроектування в Україні. Існуюча поширена термінологія землекористування не відповідає новим економічним умовам сьогодення та потребує суттєвого удосконалення, особливо в нормотворчій діяльності. Запропоновані терміни у частині визначених автором форм землеустрою можуть бути особливо актуальними для удосконалення Земельного Кодексу та основного Закону України "Про землеустрій".

\section{$\Lambda$ ітература:}

1. Подорожна Т.С. Законодавчі дефініції: поняття, структура, функції. Аьвів: ПАІС, 2009. $196 \mathrm{c}$.

2. Бондаренко В.А. Окремі аспекти використання дефініцій в адміністративно-правових нормах. Науковий вісник Ужгородського національного університету. Серія: Право, 2014. Вип. 29 (2). С. 23-26.

3. Аругак В.М. Економіка сільськогосподарського землекористування: теорія, методологія та практика: автореф. дис. на здобуття наук. ступеня А-ра екон. наук: 08.00.06 / Нац. ун-т біоресурсів і природокористування України. Київ, 2011. 38 с.

4. Кустовська О.В. Еколого-економічне обгрунтування формування сільськогосподарського землекористування: дис.... канд. екон. наук: 08.00.06 / Нац. аграр. ун-т. Київ, 2008. 255 c.

5. Економічна енциклопедія: у трьох томах. / Редкол.: С.В. Мочерний (відп. ред.) та ін. Київ: Видавничий центр "Академія", 2000. Т. 1.864 с.
6. Третяк А.М., Аругак В.М. Наукові основи економіки землекористування та землевпорядкування. Київ: ЦЗРУ, 2003. 337 с.

7. Кучер О.О. Теоретико-методологічні підходи до розробки індикаторів сталого землекористування В Україні. Вісник НАУ. 2006. Вип. 104. С. 112-116.

8. Аругак В.М. Економіка сільськогосподарського землекористування: теорія, методологія та практика: дис.... А-ра. екон. наук: 08.00.06 / Нац. ун-т біоресурсів і природокористування України. Київ, 2011. 461 с.

9. Краснолуцький О.В. Еколого-економічна ефективність використання земельних ресурсів корпоративними сільськогосподарськими підприємствами: автореф. дис. на здобуття наук. ступеня канд. екон. наук: 08.00.06 / Національний університет біоресурсів і природокористування України. Київ, 2018. 31 с.

10. DeFries R., Asner G., Houghton R. Ecosystems and Land Use Change. American Geophysical Union. 2004. Vol. 153. p. 344.

11. Курильців Р.М. Інтегроване управління землекористуванням в контексті сталого розвитку: теорія, методологія, практика: дис.... А-ра екон. наук: 08.00.06 / Нац. ун-т біоресурсів і природокористування України. Київ, 2017. 518 с.

12. Третяк А.М. Економіка землекористування та землевпорядкування: навч. посіб. Київ, $2004.542 \mathrm{c}$.

13. Рябоконь В.П. Використання земельних ресурсів господарств населення в кооперативних умовах. Економіка АПК. 2009. № 3. C. 82-87.

14. Земельний кодекс України від 25 жовтня 2001 року № 2768-III. URL: http:// zakon2.rada.gov.ua/laws/show/2874\%D0\%B0-07 (дата звернення: 21.05.2020).

15. Концептуальні засади вирішення проблем землеустрою сільських територій в сучасних умовах: монографія / Ковальчук І.П. та ін.; за ред. І.П. Ковальчука. Київ: Медінформ, 2015. 158 с.

16. Великий тлумачний словник сучасної української мови. Ірпінь: ВТФ "Перун", 2001. $1440 \mathrm{c}$.

17. Закон об утверждении основ земельного законодательства Союза ССР и союзных республик от 13 декабря 1968 года № 3401-VII. URL: http://www.economics.kiev.ua/download/ ZakonySSSR/data03/tex15219.htm (дата звернення: 21.05.2020).

18. Земельный кодекс УССР от 29.11.1922. Постановление Всеукраинского Центрального Исполнительного Комитета. URL: http:// search.ligazakon.ua/1 doc2.nsf/link1/ KP220002.html (дата звернення: 21.05.2020). 
19. Про землеустрій: Закон України від 22 травня 2003 року № 858-IV. URL: https:// zakon.rada.gov.ua/laws/show/858-15 (дата звернення: 21.05.2020).

20. Третяк А.М. Землеустрій в Україні: теорія, методологія: монографія. Херсон: Грінь А.С., $2013.650 \mathrm{c}$.

21. Кривов В.М., Тихенко Р.В., Гетьманчик І.П. Основи землевпорядкування: навч. посіб. для підготовки бакалаврів у вищ. навч. закл. II-IV рівнів акредитації; за ред. В.М. Кривова. 2-ге вид., доп. Київ: У рожай, 2009. 324 с.

\section{References:}

1. Podorozhna, T.S. (2009), Zakonodavchi definitsii: poniattia, struktura, funktsii [Legislative Definitions: Concepts, Structure, Functions], PAIS, Lviv, Ukraine.

2. Bondarenko, V.A. (2014), "Some Aspects of the Application of Definitions in the Administrative and Legal Standards", Naukovyj visnyk Uzhhorods'koho natsional'noho universytetu, Pravo, vol. 29 (2), pp. 23-26.

3. Druhak, V.M. (2011), "Economics of agricultural Land Use: Theory, Methodology and Practice", DSc. Thesis, Economics of Nature Use and Environmental Protection, National University of Life and Environmental Sciences of Ukraine, Kyiv, Ukraine.

4. Kustovs'ka, O.V. (2008), "Ecological and Economic Substantiation of Formation of Agricultural Land Use", Ph.D. Thesis, Economics of Nature Use and Environmental Protection, National Agrarian University, Kyiv, Ukraine.

5. Mochernyj, S.V. (ed.) (2000), Ekonomichna entsyklopediia [Economic Encyclopedia], vol. 1, Vydavnychyj tsentr "Akademiia", Kyiv, Ukraine.

6. Tretiak, A.M. and Druhak, V.M. (2003), Naukovi osnovy ekonomiky zemlekorystuvannia ta zemlevporiadkuvannia [Scientific Bases of Land Use Economics and Land Management], TsZRU, Kyiv, Ukraine.

7. Kucher, O.O. (2006), "Theoretical and methodological approaches to the development of indicators of sustainable land use in Ukraine", Visnyk NAU, vol. 104, pp. 112-116.

8. Druhak, V.M. (2011), "Economics of agricultural land use: theory, methodology and practice", Abstract of DSc. dissertation, Economics of Nature Use and Environmental Protection, National University of Life and Environmental Sciences of Ukraine, Kyiv, Ukraine.

9. Krasnoluts'kyj, O.V. (2018), "Ecological and Economic Efficiency of land Resources Use by Corporate Agricultural Enterprises", Ph.D. Thesis, Economics of Nature Use and Environmental
Protection, National University of Life and Environmental Sciences of Ukraine, Kyiv, Ukraine.

10. DeFries, R. Asner, G. and Houghton, R. (2004), "Ecosystems and Land Use Change", American Geophysical Union, vol. 153, p. 344.

11. Kuryl'tsiv, R.M. (2017), "Integrated Land Use Governance in the Context of Sustainable Development: Theory, Methodology, Practice", Abstract of DSc. dissertation, Economics of Nature Use and Environmental Protection, National University of Life and Environmental Sciences of Ukraine, Kyiv, Ukraine.

12. Tretiak, A.M. (2004), Ekonomika zemlekorystuvannia ta zemlevporiadkuvannia [Economics of land use and land management], Kyiv, Ukraine.

13. Riabokon', V.P. (2009), "Use of Land Resources of Households in Cooperative Conditions", The Economy of Agro-Industrial Complex, vol. 3, pp. 82-87.

14. The Verkhovna Rada of Ukraine (2001), "Land Code of Ukraine", available at: http:// zakon2.rada.gov.ua/laws/show/2874\%D0\%B0-07 (Accessed 21 May 2020).

15. Koval'chuk, I.P. et al. (2015), Kontseptual'ni zasady vyrishennia problem zemleustroiu sil's'kykh terytorij v suchasnykh umovakh [Conceptual Principles of Solving Problems of Land Management of Rural Areas in Modern Conditions], Medinform, Kyiv, Ukraine.

16. Velykyj tlumachnyj slovnyk suchasnoi ukrains'koi movy [Great Dictionary of the Modern Ukrainian Language] (2001), VTF "Perun", Irpin', Ukraine.

17. Verhovnyj sovet Sojuza SSR (1968), "The Law on the Approval of the Fundamentals of Land Legislation of the USSR and Union Republics", available at: http://www.economics.kiev.ua/ download/ZakonySSSR/data03/tex15219.htm (Accessed 21 May 2020).

18. Vseukrainskij Central'nyj Ispolnitel'nyj Komitet (1922), "The Land Code of the Ukrainian SSR", available at: http://search.ligazakon.ua/1 doc2.nsf/link1/ KP220002.html (Accessed 21 May 2020).

19. The Verkhovna Rada of Ukraine (2003), The Law of Ukraine "On Land Management", available at: https://zakon.rada.gov.ua/laws/show/858-15 (Accessed 21 May 2020).

20. Tretiak, A.M. (2013), Zemleustrij v Ukraini: teoriia, metodolohiia [Land Management in Ukraine: Theory, Methodology], Hrin' D.S., Kherson, Ukraine.

21. Kryvov, V.M. Tykhenko, R.V. and Het'manchyk, I.P. (2009), Osnovy zemlevporiadkuvannia [Fundamentals of Land Management], 2nd ed, Urozhaj, Kyiv, Ukraine.

Стаття надійшла до редакиї 22.05.2020 p. 